Section Editor

John J. Millichap, MD

\section{Obstructive sleep apnea triggered by vagus nerve stimulation}

Catello Vollono, MD,

$\mathrm{PhD}$

Filomena Fuggetta,

TNFP

Beatrice Cioni, MD

Giacomo Della Marca, $\mathrm{MD}, \mathrm{PhD}$

Correspondence to

Dr. Vollono:

lvol@libero.it

Download teaching slides: Neurology.org
A 47-year-old man with drug-resistant cryptogenic epilepsy, treated with vagus nerve stimulation (VNS), underwent polysomnography (PSG) for suspected obstructive sleep apnea (OSA). A previous PSG study, performed 1 year before VNS, had showed an apnea-hypopnea index $(\mathrm{AHI})=4$ events/hour, but the patient reported that the activation of the VNS was associated with increase of apneas witnessed by his bed partner. PSG was consistent with mild OSA; the AHI was 14.0 events/ hour. During PSG, the stimulator was active for periods of 30 seconds, generating a peculiar artifact (figure, black arrows), separated by a 3-minute interval. In $67 \%$ of the obstructive events (9.5 events/ hour), the onset of the event was simultaneous or immediately followed the start of VNS activation, suggesting that VNS might trigger obstructive apneas/hypopneas $^{1,2}$ (figure, white arrows).

\section{AUTHOR CONTRIBUTIONS}

Dr. Vollono: study concept and design, drafting the manuscript, revising the manuscript, final approval. F. Fuggetta: acquisition and analysis of data. Dr. Cioni: analysis and interpretation of data. Dr. Della Marca: study concept and design, drafting the manuscript, interpretation of data, study supervision, revising the manuscript, final approval.

\section{STUDY FUNDING}

No targeted funding reported.

\section{DISCLOSURE}

The authors report no disclosures relevant to the manuscript. Go to Neurology.org for full disclosures.

\section{REFERENCES}

1. Ebben MR, Sethi NK, Conte M, Pollak CP, Labar D. Vagus nerve stimulation, sleep apnea, and CPAP titration. J Clin Sleep Med 2008;4:471-473.

2. Parhizgar F, Nugent K, Raj R. Obstructive sleep apnea and respiratory complications associated with vagus nerve stimulators. J Clin Sleep Med 2011;7:401-407.

Figure Five minutes of PSG

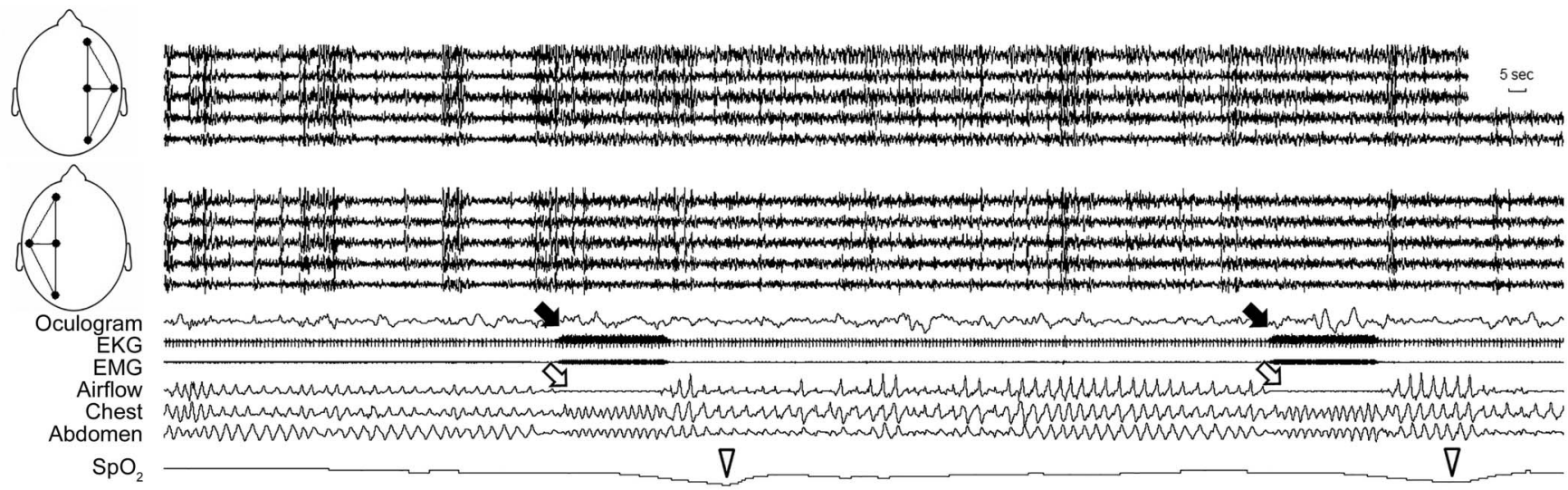

Recording montage is on the left. The stimulator activation artifact is evident on the EMG channel (black arrows). Vagus nerve stimulation activation triggers increase of respiratory rate, a consequent reduction of airflow, and, occasionally, an obstructive apnea (white arrows), followed by mild peripheral hemoglobin desaturation (arrowheads). 


\section{Neurology}

Teaching NeuroImages: Obstructive sleep apnea triggered by vagus nerve stimulation

Catello Vollono, Filomena Fuggetta, Beatrice Cioni, et al.

Neurology 2015;85; 140

DOI 10.1212/WNL.0000000000002083

This information is current as of November 2, 2015

\begin{tabular}{|c|c|}
\hline $\begin{array}{l}\text { Updated Information \& } \\
\text { Services }\end{array}$ & $\begin{array}{l}\text { including high resolution figures, can be found at: } \\
\text { http://n.neurology.org/content/85/18/e140.full }\end{array}$ \\
\hline Supplementary Material & $\begin{array}{l}\text { Supplementary material can be found at: } \\
\text { http://n.neurology.org/content/suppl/2015/10/31/WNL.000000000000 } \\
\text { 083.DC1 }\end{array}$ \\
\hline References & $\begin{array}{l}\text { This article cites } 2 \text { articles, } 0 \text { of which you can access for free at: } \\
\text { http://n.neurology.org/content/85/18/e140.full\#ref-list- } 1\end{array}$ \\
\hline Subspecialty Collections & $\begin{array}{l}\text { This article, along with others on similar topics, appears in the } \\
\text { following collection(s): } \\
\text { Sleep apnea } \\
\text { http://n.neurology.org/cgi/collection/sleep_apnea } \\
\text { Vagus nerve stimulation } \\
\text { http://n.neurology.org/cgi/collection/vagus_nerve_stimulation }\end{array}$ \\
\hline Permissions \& Licensing & $\begin{array}{l}\text { Information about reproducing this article in parts (figures,tables) or ir } \\
\text { its entirety can be found online at: } \\
\text { http://www.neurology.org/about/about_the_journal\#permissions }\end{array}$ \\
\hline Reprints & $\begin{array}{l}\text { Information about ordering reprints can be found online: } \\
\text { http://n.neurology.org/subscribers/advertise }\end{array}$ \\
\hline
\end{tabular}

Neurology ${ }^{\circledR}$ is the official journal of the American Academy of Neurology. Published continuously since 1951, it is now a weekly with 48 issues per year. Copyright (C) 2015 American Academy of Neurology. All rights reserved. Print ISSN: 0028-3878. Online ISSN: 1526-632X.

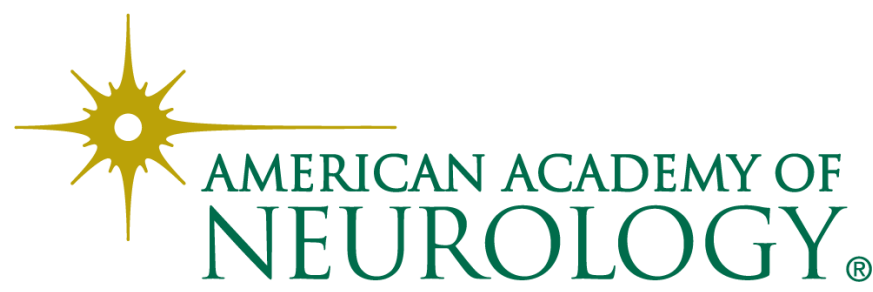

